Borgos, Anna. “Takács, Judit. 2018. Meleg század. Adalékok a homoszexualitás 20. századi magyarországi társadalomtörténetéhez ['Gay Century: Contributions to Twentieth-Century Hungarian Social History of Homosexuality'] Budapest: Kalligram. 254 pp." Hungarian Cultural Studies. e-Journal of the American Hungarian Educators Association, Volume 12 (2019) DOI: 10.5195/ahea.2019.367

\title{
Takács, Judit. 2018. Meleg század. Adalékok a homoszexualitás 20. századi magyarországi társadalomtörténetéhez ['Gay Century: Contributions to Twentieth-Century Hungarian Social History of Homosexuality'] Budapest: Kalligram. 254 pp.
}

\section{Reviewed by Anna Borgos ${ }^{1}$, HAS Institute of Cognitive Neuroscience and Psychology}

Judit Takács has for decades been working on the sociology and social history of homosexuality in Hungary. She edited the volume Homofóbia Magyarországon ('Homophobia in Hungary'), co-edited Beyond the Pink Curtain and Doing Families as well as published several other books and articles on the social exclusion of LGBT people. Her present monographic volume is the result of a five-year long research she carried out in the Institute of Sociology of the Hungarian Academy of Sciences, within the framework of a national researchproject entitled "The Twentieth-Century Social History of Homosexuality in pre-1990 Hungary." As the author situates her approach in the Introduction, it is "the historical study of social phenomena and the social-science research of historical phenomena" (20-21). The resources of the work include books, media representations, interviews, and a set of hitherto unknown archival sources. The book shows and analyzes the changing contexts of moral, legal, medicopsychological, sociological, and human-rights approaches to homosexuality in twentieth-century Hungary. This is also the history of the process by which homosexuality shifted from a practice to an identity, or, referring to Foucault, a "personality," although he ascribes this identityformation to as-early-as the late nineteenth-century. Takács also pays attention to how the specificities of language, e.g., the terms referring to gay and lesbian people, are themselves telling clues signifying and disclosing social attitudes.

Most of the sources and statements in the book are about gay men. This must be due to the fact that women's same-sex relationships were not legally discriminated in Hungary, which is a symptom unto itself and which does not necessarily attest to greater acceptance but rather to lesser social significance. Accordingly, one can find much fewer resources on women, making the history of lesbians even more invisible than that of gay men. Takács could rely only on some exceptional court and state-security cases, among them the infamous defamation lawsuit made by Cécile Tormay (Hungarian writer and founder of the conservative Magyar Asszonyok Nemzeti Szövetsége ['National Alliance of Hungarian Women'] and her secret lover Mrs. Zichy Eduardina Pallavicini against Rafael Zichy (on which see: Anita Kurimay, "Interrogating the Historical Revisionism of the Hungarian Right: The Queer Case of Cécile Tormay," East

${ }^{1}$ borgos.anna@ttk.mta.hu

$($ (c) $)$ EY

UILIS D-Sonk
New articles in this journal are licensed under a Creative Commons Attribution 4.0 International License.

This journal is published by the University Library System of the University of Pittsburgh as part of its D-Scribe Digital Publishing Program and is cosponsored by the University of Pittsburgh Press 
Borgos, Anna. “Takács, Judit. 2018. Meleg század. Adalékok a homoszexualitás 20. századi magyarországi társadalomtörténetéhez ['Gay Century: Contributions to Twentieth-Century Hungarian Social History of Homosexuality'] Budapest: Kalligram. 254 pp." Hungarian Cultural Studies. e-Journal of the American Hungarian Educators Association, Volume 12 (2019) DOI: 10.5195/ahea.2019.367

European Politics and Societies: and Cultures, 30.1, 2016, 10-33, and the article by Louise O. Vasvári in this volume).

In the first chapter Takács explores the traces of social control and the special attention directed by the Hungarian state toward homosexual people. The history of the state's listing and registration of homosexuals during the twentieth century shows that it was done in all its political regimes from early twentieth-century police to "state-socia-lists." Different and questionable statistics, made by medical and police sources, appeared throughout this period and detailed the number and attributes of homosexuals. Takács introduces an especially valuable document: a 1942 letter from the Ministry of Defense to the State Defense Center about the (ultimately rejected) possibility of drafting homosexuals for labor service, including detailed data of nearly one thousand homosexual men. To date this is the only available material documenting persecution of homosexual men in Hungary during World War II. As for the state-socialist listings (especially pre-1961 ones), homosexuality showed up mostly in the context of prostitution, blackmail and the recruiting of state informers.

The title of the second chapter indicates that it provides an overview of the representation of homosexuality and gender transgression in early twentieth-century Hungarian press; but in fact this chapter presents a more specific study of one newspaper, Az Est ['The Evening'], a widely-read political, semi-tabloid daily published between 1910 and 1939. Takács explores ninety-two articles in it that report on gender transgressions and fourty-three accounts of criminal cases related to homosexuality. These items thus cover professional gender benders (drag performers or ones who needed to pass in a job), cross-dressers, intersexual persons, and news of sex-change of certain personages from Europe and the United States (including abundant discussions of the transformation of the Danish painter Lili Elbe turned Einar Wegener). The majority of the crime accounts are related to prostitution, blackmail, robbery, murder, or seduction. Broken-heart tragedies and suicides are also recurrent themes, and the Tormay case is also frequently discussed. In addition to these affairs, Takács refers to the newspaper's presumably conscious concealment of certain other sensitive cases, probably for ethical or legal or financial reasons. Nevertheless $A z$ Est had an important contribution to the process by which topics of homosexuality and gender-bending had gradually become part of public discourse. Due to its mostly neutral or sympathizing tone, the paper thus promoted acceptance of socially stigmatized or tabooed phenomena and people even if it did so by way of piquant stories. As the author puts it, the medical experts quoted in it served as "gate-keepers" between tolerated and accepted behaviors or lifestyles, which, as said, at that time were treated more as a practice than as an identity. Nevertheless, discussing the transgression of boundaries at the same time also designated these very boundaries.

The third chapter introduces another unique source: a paper submitted to and discussed in 1958 by the Neuro-Psychiatric Committee of the Health Scientific Council (working within the Ministry of Health). This paper (allegedly inspired by an "abolitionist activist" who was "affected" himself) is explicit evidence showing that the 1961 decriminalization of homosexuality had been prepared by the state's psychiatric institution. The influence of the Wolfenden report from 1957, which helped facilitate the decriminalization of homosexuality in Great Britain, is also likely in the paper. The detailed recommendation of decriminalization justified the abolitionist arguments, emphasizing the negative social consequences of criminalization. The concept of biological origin of homosexuality was also a point of reference 
Borgos, Anna. “Takács, Judit. 2018. Meleg század. Adalékok a homoszexualitás 20. századi magyarországi társadalomtörténetéhez ['Gay Century: Contributions to Twentieth-Century Hungarian Social History of Homosexuality'] Budapest: Kalligram. 254 pp.” Hungarian Cultural Studies. e-Journal of the American Hungarian Educators Association, Volume 12 (2019) DOI: 10.5195/ahea.2019.367

in the arguments supporting decriminalization. The paper also rejected the forced treatment of homosexuals, but Gyula Nyírö, the Head of the Council, contested this rejection. By assigning the age of consent (twenty), the new legislation at last applied to lesbians as well. As for the no less sanctioned "scandalizing" nature of homosexual acts, it could be attested to by even one person, who could (and often would) be a policeman. The social condemnation of homosexuality and the suppressed, closeted, or double life it created, although softened, was far from stopping after 1961.

The manifold oppression caused by the condemnation of homosexuality is dealt with in the fourth chapter of Takács's book, in which she explores the social circumstances of same-sex attraction up until the 1989-1990 regime change, and more specifically between the 1950s and 1980s. This part of the study is based on in-depth interviews as well as on archival materials about police procedures, including four hundred and fifty court trials of "unnatural fornication" carried out between 1951 and 1962. The documents of various authorities and the personal accounts of fifty-six by-now elderly gay men and four lesbians are all put together and thus reinforce the voices and claims of one another. In the last decade two documentaries and their equivalent volumes were created on the basis of interviews with elderly Hungarian lesbians (Eltitkolt évek ['Secret Years']) and gay men (Meleg férfiak, hideg diktatúrák ['Hot Men, Cold Dictatorships']). Both films were directed by Mária Takács, and the books were edited by Anna Borgos (Eltitkolt évek, Labrisz, 2011) and Péter Hanzli (Meleg férfiak, hideg diktatúrák, Civil Müvek, 2015) respectively. It is important in itself that we can hear the voices of gay people themselves and not only those of the authorities or medical experts talking about them. According to Takács's conclusion to this chapter, the interviews demonstrate the vagueness of self-definition, the cognitive and emotional isolation experienced by gay people, the lack or onesidedness of representations, the special use of urban spaces, and the constraint of opting for a heterosexual facade (by marriage, closeting, or totally suppressing one's same-sex desires). These sources also illuminate the vague boundaries of private life during the Kádár Era in general and in gay people's lives in particular.

The fifth chapter discusses in detail two cases from the 1960s in which homosexuality appears as a tool for disqualifying churchmen or disrupting religious circles. One is a homosexual vicar's trial records (the appendix presents this man's detailed confession about his partners, thus vividly unfolding the world of gay subculture in twentieth-century Budapest). The other case is about a Dominican nun falsely "accused" of being a lesbian and of seducing young female members of the community she organized. This absurd story shows that (as the author rightly points out), just like anti-Semitism without Jews, so can homophobia without gays manifest itself. The two cases discussed in this chapter also demonstrate how Kádár's consolidation gradually turned from state-security actions to prevention measures.

In the appendix to the book a few valuable and unique resources (letters, minutes, confessions, and articles) are published.

There are some redundant parts among the book's chapters (mostly regarding the history of anti-homosexual legislation), which could have been avoided by a more careful editing, but on the whole they do not disturb the flow of reading. Another issue is that Takács had published some parts of this book in journals or edited volumes, sometimes jointly with other researchers (Gábor Csiszár and Tamás P. Tóth) who appear in the book's "Acknowledgements" and in the footnotes of the chapters, but it would have been good to make their contributions clearer. 
Borgos, Anna. “Takács, Judit. 2018. Meleg század. Adalékok a homoszexualitás 20. századi magyarországi társadalomtörténetéhez ['Gay Century: Contributions to Twentieth-Century Hungarian Social History of Homosexuality'] Budapest: Kalligram. 254 pp." Hungarian Cultural Studies. e-Journal of the American Hungarian Educators Association, Volume 12 (2019) DOI: 10.5195/ahea.2019.367

Judit Takács's Meleg század is a significant contribution to the history of sexuality in Hungary and to wider social history as well. A great merit of this volume is the uncovering and interpretation of diverse sources in light of one another, and the careful reconstruction of cases and processes while considering their wider social and historical context. Due to presently available sources and discourses, this work reveals more on the (exclusionist) social and legal environment of the time and place under study than on the experiences of the excluded LGBT people themselves, although these two points of view can hardly be separated regarding LGBT history of the twentieth century in Hungary as elsewhere. Hopefully the access to and the exploration of further sources on this topic will result in further valuable publications. 